\title{
Performance measurement of public hospitals through the integration of SWOT and balanced scorecard
}

\author{
Yuli Setiawannie*, Tiara Rahmania \\ Department of Industrial Engineering, Faculty of Engineering and Computer Science, Universitas Potensi Utama, Km 6.5 No. 3-A \\ Tanjung Mulia, Sumatera Utara 59391, Indonesia
}

\begin{tabular}{l} 
ARTICLE INFORMATION \\
\hline Article history: \\
Received: June 12, 2019 \\
Revised: September 02, 2019 \\
Accepted: September 19, 2019 \\
\hline Keywords: \\
Balanced Scorecard \\
Performance Measurement \\
Hospital Performance \\
SWOT \\
\\
Yuli Setiawannie \\
E-mail: setiawannie79@ gmail.com
\end{tabular}

\section{A B S T R A C T}

Performance measurement is an essential factor for an organization to control the implementation of the strategy. The existing performance measurement system only evaluates financial performance. This study aims to propose the Key Performance Indicators (KPI) and measuring hospital performance with SWOT and BSC integration. Stages of research are determining internal and external factors with SWOT analysis, formulating alternative strategies, translating strategies into BSC perspective on strategic maps, determining performance indicators (KPI), KPI validation with AHP to obtain indicator weights for each view, and measuring hospital performance. Based on the results of the study, performance indicators (KPI) for hospitals based on the Balanced Scorecard perspective are six financial perspective indicators, two customer perspective indicators, four internal process perspective indicators, and five growth and learning perspective indicators. The internal process perspective is $90.43 \%$, which means that the performance of the hospital is very healthy with the AA category, and learning $68.89 \%$ means that the performance of the hospital is very healthy with category A.

\section{INTRODUCTION}

The hospital is one of the health facilities that aims to realize health status standards and can reach all levels of society (Minister of Health Decree No. 129 of 2008). The fact is its management still not following community expectations yet. It means that the public wants the hospital to provide health services related to patient needs efficiently, quickly, accurately, and at affordable costs. Performance measurement is necessary to improve public health status. The hospital can carry out healing, prevention, and promotion efforts to increase hospital profits without forgetting the hospital's social functions required in the future [1].

Measurement of organizational performance is a process of evaluating the implementation of an organization's work capabilities based on specific standards [2], [3]. Performance measurement methods so far still have weaknesses that only look at financial performance. Useful performance measurement should be able to translate the 
vision, mission, and strategy of an organization into operational objectives and performance measures, both financial and non-financial aspects [4], [5].

Balanced Scorecard as a method of performance measurement used widely in manufacturing companies, but can also be applied to hospitals that are engaged in services. The implementations of the Balanced Scorecard (BSC) in the service sector for the measurement of hospital performance in China has a positive impact on improving hospital performance, influenced by operational scope/scale factors, technology quality (ranking), and completeness of medical resources equipped by the hospital [6]. The same opinion was expressed by Chow et al. [7], who advocated the application of the Balanced Scorecard for performance measurement in health organizations [8]. BSC can reflect new thinking in the era of competition in organizational effectiveness, and balance between financial performance measures and non-financial performance measures. BSC can assist companies in knowing and evaluating their overall performance.

The Hospital has programs that provide added value to customers, employees, and the community and support regional and national economic growth. The performance evaluation of the hospital influences the successful implementation of the programs. However, this hospital still emphasizes performance appraisal on financial and service aspects only. The effect is the hospital set a program without considering the right strategy up. Improved performance will be better if the measurement of non-financial performance, which is the source of financial performance, is also the focus of attention. To minimize these weaknesses, a more accurate and comprehensive performance measurement system is needed that can provide alternative strategies for companies such as the implementation integration of SWOT and a balanced scorecard. The advantage of a combination of SWOT analysis and the Balanced Scorecard is to provide a strategic balance between financial performance and non-financial performance in designing strategies well in the future. This integration can also overcome weaknesses in the BSC which tend to focus on internal problems. [9], [10]. With this integration, performance measurement can include internal and external aspects of the company [11].
The study conducted regarding previous studies that have explicitly existed about measuring performance in the health sector. One of the reviews that have done is "The Implementation of the Balanced Scorecard as a Performance Measurement Tool at the Regional General Hospital Dr. Harjono Ponorogo"[12]. The research aims to measure hospital performance with a balanced scorecard approach and compare it with traditional hospital performance measurements. The results of the overall performance measurement using the balanced scorecard at Dr. Harjono Ponorogo Hospital in 2011-2013 were in very healthy condition category $A$ with a total score of $76,24 \%$. The difference between these two kinds of research in this study uses the integration of SWOT and a balanced scorecard to measure hospital performance. Before arriving at the final assessment of hospital performance conditions, it is necessary to develop a strategy, a strategy map, to determine its performance indicators ( KPI). This study uses the validation of Key Performance Indicators with AHP to determine the weight of indicators for each perspective. In the previous research, there was no SWOT analysis to formulate the strategies that are very necessary to see the internal and external conditions of the hospital. This study aims to propose Key Performance Indicators (KPI) and measure hospital performance with the integration of SWOT and BSC. Through this research, it is expected to be able to propose performance indicators along with their weighting and assess Hospital performance with the integration of SWOT and Balanced Scorecard.

\section{RESEARCH METHODS}

The object of research is a hospital, which is one of the business units of a Pelindo I subsidiary, in Medan Belawan, North Sumatra. This research is based on observations and interviews with directors and managers who know about conditions, work activities, and service programs and labor in hospitals as SWOT data using the SWOT Balanced Scorecard Development Tool [13], [14].

This study uses a questionnaire consisting of a SWOT research questionnaire and a paired survey. SWOT research questionnaire for ten respondents who are top and middle-level managers of the hospital. The purpose of this 
questionnaire is to obtain the total value of weights from internal factors (strengths and weaknesses) and external factors (opportunities and threats). Paired Questionnaire scores for KPI validation [15], [16] based on expert opinion. The experts chosen came from the inside of the hospital, were directors, and also field managers who knew about the condition of the hospital. Experts from external parties, namely the head of the association of chiefs of hospitals who understand the performance measurement system and indicators. KPI validation using the AHP method [17], [18] (using expert choice version 11 software) to obtain the weight of performance indicators in each BSC perspective. In detail, the research diagram in Fig. 1.

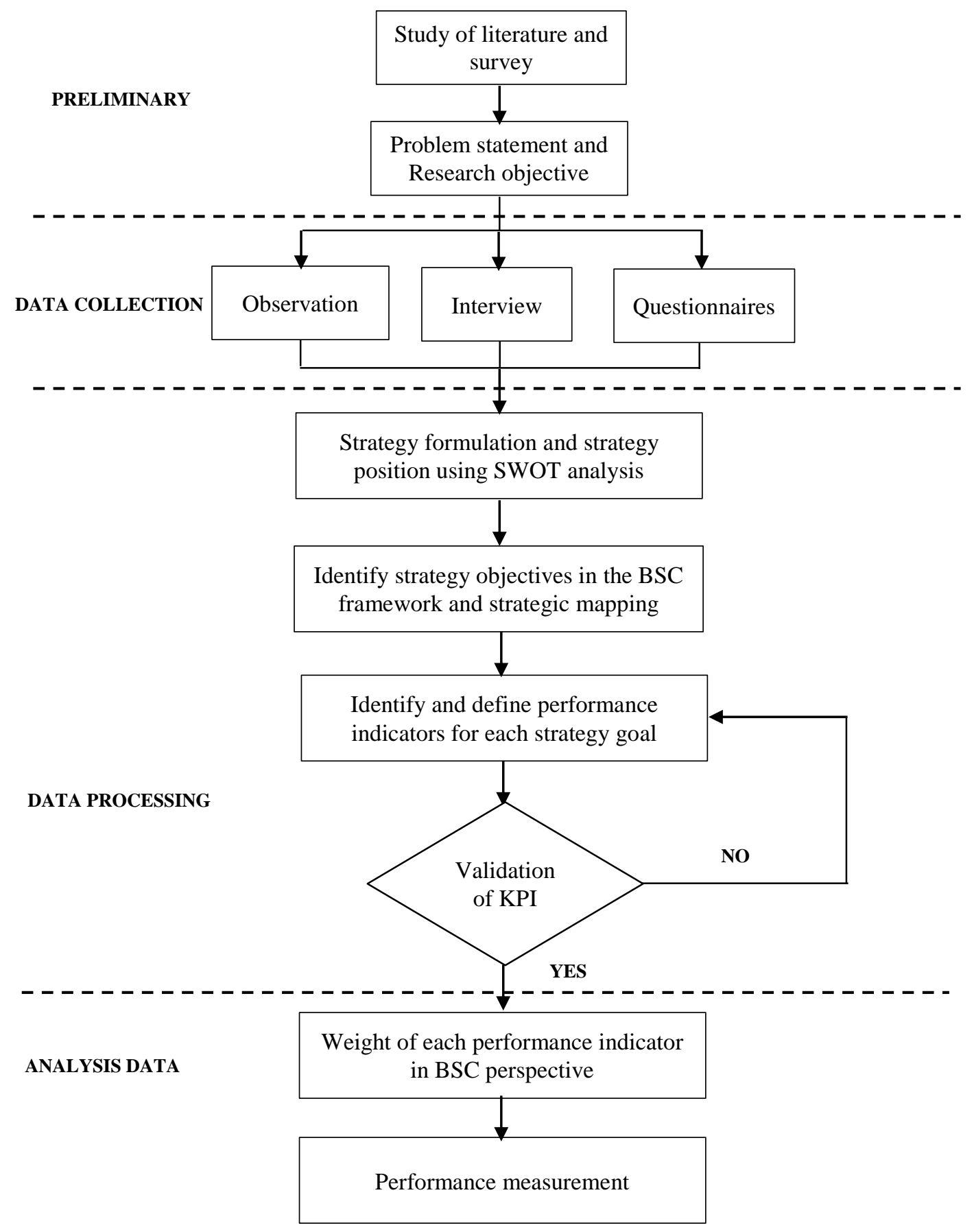

Fig. 1. Research flowchart 


\section{RESULTS AND DISCUSSION Strategic Position Determination and Hospital Strategy Formulation}

Based on the results of processing the SWOT research questionnaire, it can be determined the total weight value obtained [19]:

Total weight: relative weight $\mathrm{x}$ rating

Y-axis value: total opportunity weight - total threat weight

$\mathrm{X}$-axis value: total strength weight - total weakness weight

From the calculation, the total weight of strength is 1.68 , and the total weight of weakness is 1.33 . The difference in value between the two or $\mathrm{X}$-axis value is (+) 0.35 . The entire opportunity weight is 2.07 , and the total threat weight is 1.14 , with the Y-axis amount is (+) 0.94. The company's strategic position in the SWOT cartesian diagram is determined by connecting the values of the $\mathrm{X}$ axis and the Y-axis [20], [21].

Fig. 2 shows the position of the Hospital " $\mathrm{X}$ " is in quadrant I, which illustrates that the strength indicator exceeds the total value of weakness and the opportunity indicator exceeds the threat indicator. So that the hospital supports an aggressive growth policy. When the vector direction stays in a dynamic quadrant, it means that the company is in an excellent position to utilize various internal strengths to (1) take advantage of external opportunities, (2) overcome internal weaknesses, and (3) avoid multiple external threats. Therefore, market penetration strategies, product development, backward integration, forward integration, horizontal integration, diversification, or a combination of these all make a reasonable choice, depending on the specific situation faced by the company [22]. Aggressive strategy following the current condition of the hospital which has a vision: "To become the Best Type-C Hospital in North Sumatra" supported by the following mission:

1. Provide the best service to the community.

2. Provide complete health facilities and infrastructure in its class.

3. Become an organization that grows effectively and efficiently.

The formulating strategies are not all arranged in the SWOT matrix, but chosen strategies that can solve strategic issues [9]. In this study, a SWOT analysis was conducted to overcome the weaknesses of the BSC method, which only assesses performance from an internal perspective. The integration with the SWOT analysis, the performance measurement can include internal and external factors of the hospital.

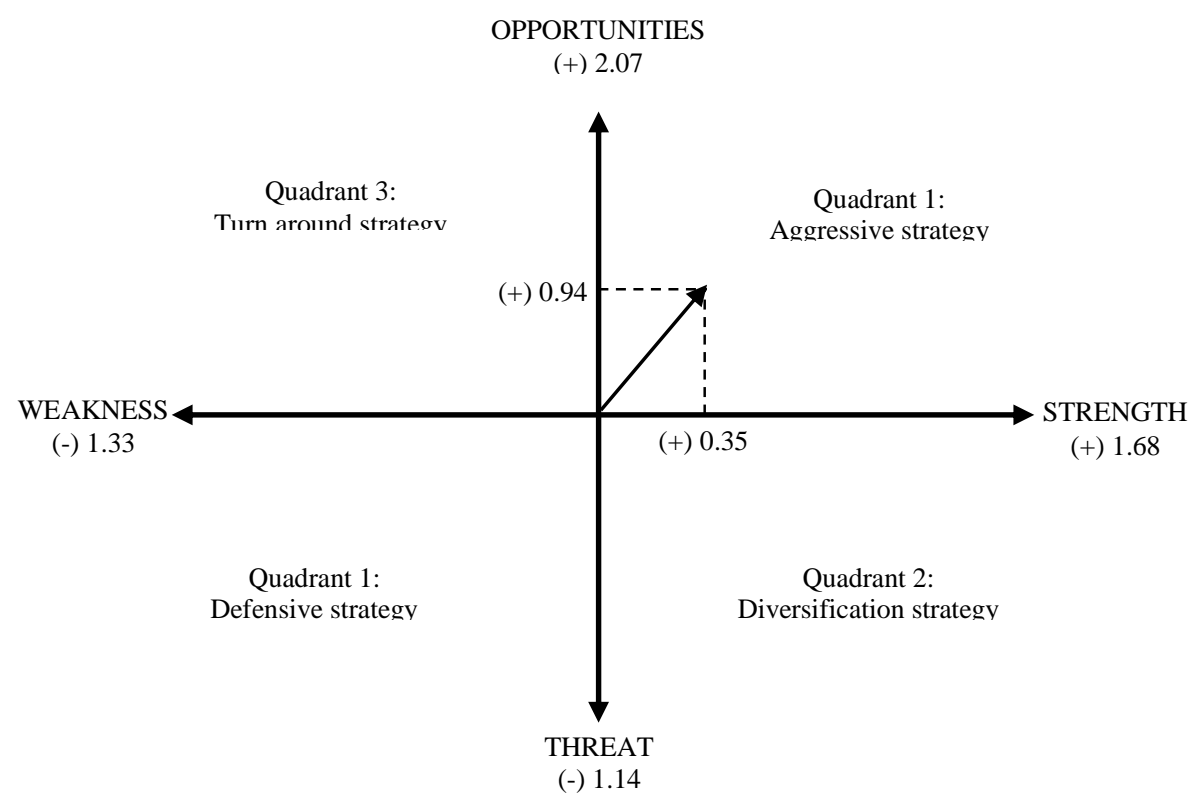

Fig. 2. Position of the hospital "X" in the SWOT analysis 
Table 1. SWOT matrix

\begin{tabular}{|c|c|c|}
\hline EXTERNAL & $\begin{array}{l}\text { STRENGTH } \\
\text { 1. Salaries of employees (nurses } \\
\text { and medical) above the } \\
\text { average hospital employees } \\
\text { 2. Experience and spirit of } \\
\text { continuous change } \\
\text { 3. Become a certified hospital } \\
\text { for Seaman Medical Check- } \\
\text { Up } \\
\text { 4. Support from stakeholders } \\
\text { (PELINDO I) } \\
\text { 5. Has been known by the } \\
\text { surrounding community } \\
\text { 6. Has several inpatients, } \\
\text { outpatient and clinic services } \\
\text { 7. Young and passionate } \\
\text { employees }\end{array}$ & $\begin{array}{l}\text { WEAKNESS } \\
\text { 1. Some positions in the } \\
\text { organizational structure } \\
\text { are empty } \\
\text { 2. Service system operation } \\
\text { that is not optimal causes } \\
\text { customers to choose to } \\
\text { move } \\
\text { 3. Information technology } \\
\text { systems that are not yet } \\
\text { integrated } \\
\text { 4. The capacity and quality } \\
\text { of equipment is } \\
\text { incomplete } \\
\text { 5. A work culture that is not } \\
\text { so good } \\
\text { 6. Less effective spatial / } \\
\text { master plan } \\
\text { 7. The number and } \\
\text { competency of human } \\
\text { medical resources are } \\
\text { inadequate }\end{array}$ \\
\hline $\begin{array}{l}\text { OPPORTUNITIES } \\
\text { 1. The excellent name PELINDO I is the } \\
\text { main attraction in hospital branding } \\
\text { 2. Market potential in the Belawan area is } \\
\text { still undersupplying because many } \\
\text { requests not addressed yet } \\
\text { 3. The scope of competition in the Belawan } \\
\text { area is always good for the development } \\
\text { of hospital services } \\
\text { 4. Potential primary health care facilities } \\
\text { spread in Belawan (Puskesmas, clinics) } \\
\text { as referral partners } \\
\text { 5. Newmarket potential of BUMN } \\
\text { employees in Medan and surrounding } \\
\text { areas } \\
\text { 6. Optimization of Trauma Center services } \\
\text { 7. The market potential of BPJS and } \\
\text { without BPJS is still broad }\end{array}$ & $\begin{array}{l}\text { O-S STRATEGIES } \\
\text { 1. Improving superior service } \\
\text { 2. Increase investment capital } \\
\text { for health service facilities } \\
\text { and infrastructure } \\
\text { 3. Increasing cooperation with } \\
\text { partners in service operations } \\
\text { 4. Strengthening the HR } \\
\text { management system } \\
\text { 5. Increasing the number of } \\
\text { BPJS card usage } \\
\text { 6. Increase the number of } \\
\text { external customers for } \\
\text { medical check-ups }\end{array}$ & $\begin{array}{l}\text { O-W STRATEGIES } \\
\text { 1. Increase HR competence } \\
\text { 2. Implement a measurable } \\
\text { performance management } \\
\text { system (reward and } \\
\text { punishment) } \\
\text { 3. The realization of reliable } \\
\text { facilities and integrated } \\
\text { information systems } \\
\text { 4. Increase the investment } \\
\text { budget for the } \\
\text { development of the master } \\
\text { plan }\end{array}$ \\
\hline $\begin{array}{l}\text { THREATS } \\
\text { 1. Market potential in the city area of } \\
\text { Medan and surrounding areas is } \\
\text { saturated } \\
\text { 2. Development of competitor hospitals } \\
\text { faster } \\
\text { 3. Quality and service products of } \\
\text { competitors are more attractive } \\
\text { 4. Changing system policy by the } \\
\text { government (every two years) } \\
\text { 5. Inadequate facilities and infrastructure } \\
\text { (such as parking areas, patient comfort, } \\
\text { and canteens for employees) }\end{array}$ & $\begin{array}{l}\text { T-S STRATEGIES } \\
\text { 1. Achieve Excellent Good } \\
\text { Service (includes: timely } \\
\text { service, interactive } \\
\text { communication with patients, } \\
\text { and accessibility of services) } \\
\text { 2. Realizing reliable facilities for } \\
\text { customer satisfaction } \\
\text { 3. The realization of satisfaction } \\
\text { for stakeholders }\end{array}$ & $\begin{array}{l}\text { T-W STRATEGIES } \\
\text { 1. The recognition of Good } \\
\text { Corporate Governance } \\
\text { 2. The realization of } \\
\text { competent and integrity } \\
\text { HR } \\
\text { 3. The realization of an } \\
\text { integrated service system }\end{array}$ \\
\hline
\end{tabular}


Table 1 shows the hospital strategy formulation using the SWOT matrix by combining various indicators of strengths, weaknesses, opportunities, and threats to the hospital. Based on the calculation of the total score for each strategy, the $\mathrm{O}-\mathrm{S}$ strategies has a score of 3.75 , the score of the $\mathrm{O}-\mathrm{W}$ strategies is 3.40 , the T-S strategies gets a score of 2.81, and the T-W strategies receives a score of 2.47. O-S strategies are the following work program that has been run by the hospital because the strategy uses all the strength to take advantage of the opportunities that exist.

\section{Hospital Balanced Scorecard Strategy Map}

Hospital aggressive strategy, if it is associated with alternative strategies in the SWOT matrix, the OS strategies is following the work program that has been run by the hospital. The suitability of OS strategy because it has used all the power to take advantage of opportunities that exist. Strategy map formulation ground on the 2018 National Edition Hospital Accreditation Standard (SNARS). SNARS hopes that hospitals can improve the quality of services, especially inpatient safety and provide a safe and efficient work environment. This service improvement is expected to be able to improve employee performance and motivate internally in increasing the use of technology for integrated services. In addition, the Minister of Health's regulations regarding hospital minimum service standards and costs in the health insurance program also form the basis for developing hospital strategic maps.

The results of the translation of strategy alternatives illustrate the causal relationship between vision, mission, strategy, and strategic goals based on the perspective of the BSC (finance, customers, internal processes, and hospital growth and learning [23], [24].

Hospital BSC Strategy Map "X" (Fig. 3), shows that other strategic objectives influence earnings growth as a final performance appraisal from a financial perspective in the financial aspect [25]. From the customer perspective, customer satisfaction will increase if the service and operational performance of the hospital have good quality. An internal process perspective, which is improving hospital operational performance, can affect the customer perspective. Optimal hospital operational performance can realize through qualified and competent human resources in their fields, which are targets from a strategic goal of growth and learning perspectives.

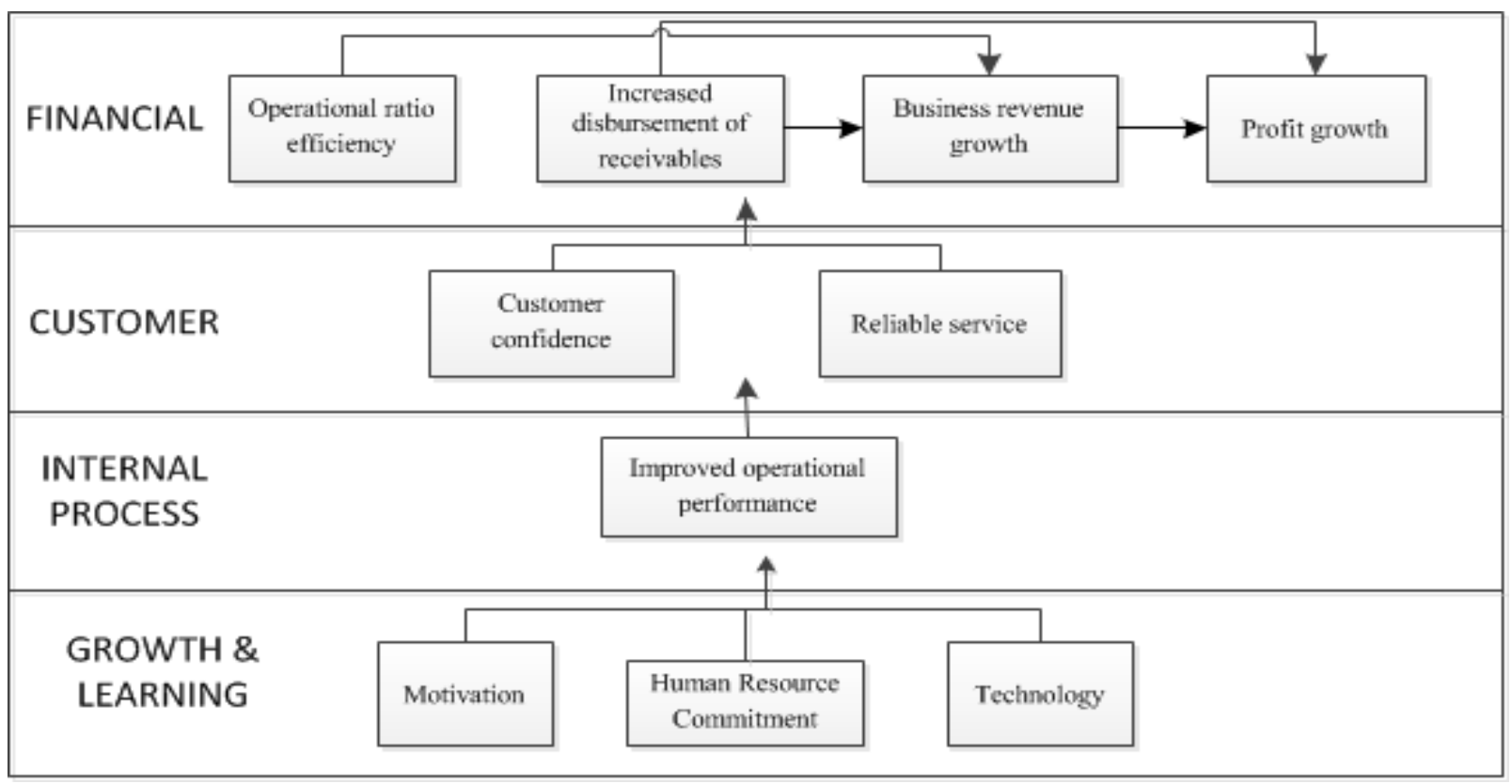

Fig. 3. BSC strategy map of "X" hospital 


\section{Formulation of Key Performance Indicators (KPI)}

Key Performance Indicators are measures or indicators that control performance that must be carried out for the success of achieving the desired company performance both now and in the future [26], [27], [28], [29], [30], and [31]. Performance indicators are formulated based on performance standards established by the Indonesian Ministry of Health in 2005 and service quality standards, according to SNARS edition 1 of 2018. The design of KPI indicators based on the four BSC perspectives obtained from the strategy map and interviews with the Director of PT. PHCM and representatives from management who understand the performance measurement indicators and support from primary hospital data relating to the four BSC perspectives.

\section{Validation of Key Performance Indicators (KPI)}

The next step after the hospital KPI indicator has been identified is expert judgment through a paired questionnaire from the KPI indicator. The results of paired questionnaire data processing are validated by the AHP method to obtain the weight of each perspective, which is a priority measurement of performance in each KPI perspective $\mathrm{BSC}$. This validation process is what distinguishes this research from other research on hospital performance measurement, for example, in research [32], which did not validate the KPI indicators for each perspective.

Table 2. Total weight of overall KPI in each BSC perspective

\begin{tabular}{llll}
\hline Perspective & \multicolumn{1}{c}{ Strategic target } & \multicolumn{1}{c}{ KPI } & Weight \\
\hline $\begin{array}{l}\text { Operational ratio } \\
\text { efficiency } \\
\text { Increased disbursement } \\
\text { of receivables }\end{array}$ & $\begin{array}{l}\text { Operating Ratio (OR) } \\
\text { Disbursement rate of trade } \\
\text { receivables }\end{array}$ & 0.070 \\
Business & growth & $\begin{array}{l}\text { Realization of operating } \\
\text { income } \\
\text { Increase in the number of } \\
\text { general patients }\end{array}$ & 0.018 \\
Return on Capital \\
Employed (ROCE) \\
Realization of profit before \\
Profit growth
\end{tabular}


The paired questionnaire validation between the BSC perspective and the AHP (using expert choice version 11) had an inconsistency value (CR) of 0.08 (the assessment results were acceptable because of CR CR 10\%). The biggest priority is on the perspective of growth and learning that is the perspective of 0.406 , which shows that the directors of the ' $\mathrm{X}$ ' Hospital want to create competent and reliable human resources in their fields. Meanwhile, the lowest weight in the customer's perspective is 0.148 . Hospitals need to improve aspects of human resources and service facilities in advance to increase the number of customers and satisfaction. The financial perspective has a weight of 0.237 and 0.208 for the standpoint of internal process perspectives.

The results of KPI validation also produced the total weight of the overall KPI in each BSC perspective [12] as a priority indicator in obtaining total hospital performance scores (Table 2). The inconsistency value for the total validation of the overall weight of the KPI is 0.09 , so the results of the paired questionnaire assessment for each KPI indicator can be accepted because 0.09 is smaller than $10 \%$. Based on the total weight of the KPI from the BSC (Table 2), the highest priority of the KPI lies in the employee productivity indicator (internal process perspective) of 0.19 and the lowest is the Average Length of Stay (ALOS) indicator on the internal process perspective of 0.014. This indicator shows that hospital management is trying to improve HR productivity so that it can fulfill its vision, mission, and strategic goals and has the advantage of competing with aggressive strategies (OS strategies in the TOWS matrix). Management still needs to increase attention to the quality of operational services, especially inpatient services in hospitals, because of the low weight of the assessment of operational performance indicators.

\section{Hospital Performance Measurement}

Measurement of hospital performance was carried out in the 2017-2018 period based on hospital data processing, a comparison of performance between 2017 and 2018 (Table 3). Measuring the total performance scores of the four perspectives (BSC) by the weight of each KPI is used in each BSC perspective (Table 2). Adjustment of the total score obtained by the criteria of total performance score aims to see the condition of hospital performance. With this research, it can be seen the condition and category of the hospital after processing hospital data and determining the weight of the indicator through KPI validation. In existing research on hospital performance measurement [33], performance measurement only compares performance realization with performance targets set by the hospital without comparing the standard conditions of company performance [34].

Based on the results of comparisons of performance in 2017 and 2018, management needs to pay attention to some indicators that have decreased, such as a decrease in the number of patients, employee satisfaction, and empowerment of human resources. The decrease in the number of patients indirectly Affects customer satisfaction, although not significantly. The management needs to evaluate the service quality standards that cause customers to be less satisfied with the services currently received.

The employee is a critical asset in an organization. Even though overall, the indicators are still good, the decrease in employee satisfaction can be a management evaluation of the policy towards employees. In the world of services, employees have a critical role in increasing patient satisfaction related to the service process. Management should involve employees in establishing policies relating to employee rights and obligations and service procedures that can increase patient satisfaction.

The performance of the hospital included in the very healthy condition of the AAA category because the total performance score is $110.89 \%$ for the financial perspective and $100.1 \%$ for the customer perspective (Table 4). The total performance score was $90.43 \%$ for the internal process perspective, that means the hospital's performance included in the excellent condition category AA. The overall performance score is $71.36 \%$ for the aspect of growth and learning, that meaning hospital performance included in the very healthy condition category $\mathrm{A}$. The growth and learning perspective has the lowest performance score compared to other aspects. This perspective has more to do with motivating and encouraging employees to improve the company's growth and development process 
Table 3. Comparison of 2017-2018 period performance

\begin{tabular}{|c|c|c|c|c|}
\hline \multirow{2}{*}{ Perspective } & \multirow{2}{*}{ KPI } & \multicolumn{2}{|c|}{ Performance } & \multirow{2}{*}{ Performance comparison } \\
\hline & & 2017 & 2018 & \\
\hline \multirow{6}{*}{ Finance } & Operating ratio $(\mathrm{OR})$ & $76.7 \%$ & $84.2 \%$ & An increase of $7.5 \%$ in 2018 \\
\hline & $\begin{array}{l}\text { Disbursement rate of } \\
\text { trade receivables }\end{array}$ & $100 \%$ & $98 \%$ & A decrease of $2 \%$ from 2017 \\
\hline & $\begin{array}{l}\text { Realization of } \\
\text { operating income }\end{array}$ & $89.9 \%$ & $95.6 \%$ & An increase of 5.7\% from 2017 \\
\hline & $\begin{array}{l}\text { Increase in the number } \\
\text { of general patients }\end{array}$ & $13 \%$ & $6 \%$ & $\begin{array}{l}\text { A decrease in the number of patients by } \\
5 \% \text { from } 2017\end{array}$ \\
\hline & $\begin{array}{l}\text { Return on Capital } \\
\text { Employed (ROCE) }\end{array}$ & $10.3 \%$ & $21.6 \%$ & Increased by $11.3 \%$ from 2017 \\
\hline & $\begin{array}{l}\text { Realization of profit } \\
\text { before tax }\end{array}$ & $35.3 \%$ & $99 \%$ & $\begin{array}{l}\text { A high increase from } 2017 \text { amounted to } \\
63.7 \%\end{array}$ \\
\hline \multirow[t]{2}{*}{ Customer } & $\begin{array}{l}\text { Customer satisfaction } \\
\text { (Likert scale) }\end{array}$ & 3.86 & 3.85 & $\begin{array}{l}\text { Customer satisfaction is considered good } \\
\text { because in } 2017 \text {, and } 2018 \text { shows the range } \\
\text { of satisfaction exceeds level } 3 \text { (meaning } \\
\text { quite satisfying) }\end{array}$ \\
\hline & $\begin{array}{l}\text { Follow up on customer } \\
\text { complaints }\end{array}$ & $100 \%$ & $100 \%$ & $\begin{array}{l}\text { Very good in following up on customer } \\
\text { complaints, because stable values are } \\
\text { shown in both periods }\end{array}$ \\
\hline \multirow{4}{*}{$\begin{array}{l}\text { Internal } \\
\text { process }\end{array}$} & $\begin{array}{l}\text { Turn Over Interval } \\
\text { (TOI) }\end{array}$ & 2 day & 3 day & $\begin{array}{l}\text { An increase in the value of the TOI, it } \\
\text { means a decrease in the efficient use of } \\
\text { beds. But it is still in an ideal condition } \\
\text { which is } 1-3 \text { days (Indonesian Ministry of } \\
\text { Health, 2005) ) }\end{array}$ \\
\hline & $\begin{array}{l}\text { Bed Occupancy Ratio } \\
\text { (BOR) }\end{array}$ & $65 \%$ & $70 \%$ & $\begin{array}{l}\text { Still in an ideal state for a BOR value of } \\
60-80 \% \text { (Depkes RI, 2005) }\end{array}$ \\
\hline & $\begin{array}{l}\text { Average Length of } \\
\text { Stay (ALOS) }\end{array}$ & 5.2 day & 5 day & $\begin{array}{l}\text { Improved quality of care and handling of } \\
\text { patients, because ALOS has decreased. Its } \\
\text { performance is excellent because it is still } \\
\text { in an ideal condition which is } 6-9 \text { days } \\
\text { (Indonesian Ministry of Health, 2005) }\end{array}$ \\
\hline & Bed Turn Over (BTO) & $\begin{array}{l}48.9 \\
\text { times }\end{array}$ & $\begin{array}{l}45.4 \\
\text { times }\end{array}$ & $\begin{array}{l}\text { A slight decrease from 2017, the } \\
\text { performance is good because it is still in an } \\
\text { ideal condition BTO value of } 40-50 \text { times } \\
\text { (Indonesian Ministry of Health, 2005) }\end{array}$ \\
\hline \multirow{5}{*}{$\begin{array}{l}\text { Growth } \\
\text { and } \\
\text { Learning }\end{array}$} & $\begin{array}{l}\text { Employee Satisfaction } \\
\text { (Likert scale) }\end{array}$ & 4.10 & 3.85 & $\begin{array}{l}\text { Employee satisfaction has decreased from } \\
2017 \text { but is still considered good. }\end{array}$ \\
\hline & $\begin{array}{l}\text { Employee productivity } \\
\text { (Rp./Employee) }\end{array}$ & $\begin{array}{c}240.755 .8 \\
71\end{array}$ & $\begin{array}{c}330.00 \\
0.000\end{array}$ & $\begin{array}{l}\text { Employee productivity increased by } \\
27.04 \% \text { compared to } 2017\end{array}$ \\
\hline & $\begin{array}{l}\text { Implement } \\
\text { continuation of } \\
\text { hospital accreditation }\end{array}$ & $80 \%$ & $100 \%$ & $\begin{array}{l}\text { An increase in the percentage of } \\
\text { certification continues; this shows that } \\
\text { hospital management is trying to raise its } \\
\text { standards towards B-type hospitals. }\end{array}$ \\
\hline & $\begin{array}{l}\text { Increased use of } \\
\text { technology }\end{array}$ & $100 \%$ & $100 \%$ & $\begin{array}{l}\text { Excellent performance, because the value } \\
\text { is stable and fits the performance target for } \\
\text { both periods. }\end{array}$ \\
\hline & $\begin{array}{l}\text { Empowerment of } \\
\text { Human Resources }\end{array}$ & $14.4 \%$ & $8.5 \%$ & $\begin{array}{l}\text { The empowerment of human resources is } \\
\text { still lacking and also decreased } \\
\text { performance. }\end{array}$ \\
\hline
\end{tabular}


Tabel 4. Total hospital performance score

\begin{tabular}{|c|c|c|c|c|c|c|}
\hline Perspective & KPI & $\begin{array}{l}\text { Indicator } \\
\text { Weight }\end{array}$ & $\begin{array}{c}\text { Average } \\
\text { Performance }\end{array}$ & Target & $\begin{array}{c}\text { Target } \\
\text { Achievement } \\
(\%)\end{array}$ & $\begin{array}{c}\text { Score } \\
(\%)\end{array}$ \\
\hline \multirow{6}{*}{ Finance } & Operating ratio $(\mathrm{OR})$ & 0.070 & $80.47 \%$ & $80 \%$ & 100.59 & 23.39 \\
\hline & $\begin{array}{l}\text { Disbursement rate of } \\
\text { trade receivables }\end{array}$ & 0.018 & $99 \%$ & $98 \%$ & 101.02 & 6.04 \\
\hline & $\begin{array}{l}\text { Realization of } \\
\text { operating income }\end{array}$ & 0.048 & $92.74 \%$ & $100 \%$ & 92.74 & 14.79 \\
\hline & $\begin{array}{l}\text { Increase in the } \\
\text { number of general } \\
\text { patients }\end{array}$ & 0.032 & $9.50 \%$ & $10 \%$ & 95.00 & 10.10 \\
\hline & $\begin{array}{l}\text { Return on Capital } \\
\text { Employed (ROCE) }\end{array}$ & 0.022 & $52.22 \%$ & $12 \%$ & 435.17 & 31.81 \\
\hline & $\begin{array}{l}\text { Realization of profit } \\
\text { before tax }\end{array}$ & 0.111 & $67.14 \%$ & $100 \%$ & 67.14 & 24.76 \\
\hline \multicolumn{2}{|c|}{$\begin{array}{l}\text { The total financial performance } \\
\text { score }\end{array}$} & 0.301 & & & & 110.89 \\
\hline \multirow{2}{*}{ Customer } & $\begin{array}{l}\text { Customer satisfaction } \\
\text { (Likert scale) }\end{array}$ & 0.069 & 3.855 & 3.85 & 100.13 & 80.34 \\
\hline & $\begin{array}{l}\text { Follow up on } \\
\text { customer complaints }\end{array}$ & 0.017 & $100 \%$ & $100 \%$ & 100 & 19.77 \\
\hline \multicolumn{2}{|c|}{$\begin{array}{l}\text { The total customer performance } \\
\text { score }\end{array}$} & 0.086 & & & & 100.1 \\
\hline \multirow{4}{*}{$\begin{array}{l}\text { Internal } \\
\text { process }\end{array}$} & $\begin{array}{l}\text { Turn Over Interval } \\
\text { (TOI) }\end{array}$ & 0.097 & 2.4 day & 3 day & 78.83 & 43.70 \\
\hline & $\begin{array}{l}\text { Bed Occupancy Ratio } \\
\text { (BOR) }\end{array}$ & 0.027 & $68 \%$ & $70 \%$ & 97.14 & 14.99 \\
\hline & $\begin{array}{l}\text { Average Length of } \\
\text { Stay (ALOS) }\end{array}$ & 0.014 & $5.11 \%$ & 6 day & 85.08 & 6.81 \\
\hline & $\begin{array}{l}\text { Bed Turn Over } \\
\text { (BTO) }\end{array}$ & 0.037 & 47.2 times & 40 times & 117.98 & 24.94 \\
\hline \multicolumn{2}{|c|}{$\begin{array}{l}\text { The total internal process } \\
\text { performance score }\end{array}$} & 0.175 & & & & 90.43 \\
\hline \multirow{5}{*}{$\begin{array}{l}\text { Growth } \\
\text { and } \\
\text { Learning }\end{array}$} & $\begin{array}{l}\text { Employee } \\
\text { Satisfaction (Likert } \\
\text { scale) }\end{array}$ & 0.038 & 3.975 & 3.85 & 103.25 & 8.98 \\
\hline & $\begin{array}{l}\text { Employee } \\
\text { productivity } \\
\text { (Rp./Employee) }\end{array}$ & 0.190 & $\begin{array}{c}285.377 .9 \\
36\end{array}$ & $\begin{array}{l}425.000 .0 \\
00\end{array}$ & 67.15 & 29.19 \\
\hline & $\begin{array}{l}\text { Implement } \\
\text { continuation of } \\
\text { hospital accreditation }\end{array}$ & 0.108 & $90 \%$ & $100 \%$ & 90 & 22.24 \\
\hline & $\begin{array}{l}\text { Increased use of } \\
\text { technology }\end{array}$ & 0.039 & $100 \%$ & $100 \%$ & 100 & 8.92 \\
\hline & $\begin{array}{l}\text { Empowerment of } \\
\text { Human Resources }\end{array}$ & 0.062 & $11.39 \%$ & $80 \%$ & 14.24 & 2.02 \\
\hline \multicolumn{2}{|c|}{$\begin{array}{l}\text { The total score of growth and } \\
\text { learning performance }\end{array}$} & 0.437 & & & & 71.36 \\
\hline
\end{tabular}




\section{CONCLUSION}

Based on the results of data processing and research analysis, the performance indicators (KPI) for hospitals in the Balanced Scorecard perspective are six financial perspective indicators, two customer perspective indicators, four internal process perspective indicators, and five growth and learning perspective indicators. The results of determining performance indicators show that hospitals have performance priorities from a growth and learning perspective. This indicator shows the hospital's commitment to implement programs to improve the capabilities of HR and the complete health facilities and infrastructure in its class. The results of performance measurements obtain that the hospital is in very healthy condition. The performance score for each perspective is $110.89 \%$ for financial and $100.1 \%$ of customers who are in the AAA category. The internal process perspective $90.43 \%$ is in the AA category, and $68.89 \%$ growth and learning perspectives are in category A. The use of the SWOT Balanced Scorecard integration in hospitals can measure performance more comprehensively, and improve the level in the future. Future studies can add performance measurement indicators (KPI) by performance standards based on government regulations and hospital accreditation and conduct a risk analysis of performance indicators used to measure hospital performance.

\section{ACKNOWLEDGMENTS}

The author would like to thank for the program of activities sponsored and funded by the Ministry of Research and Technology of Higher EducationDirectorate General of Research Strengthening and Development-Research Grant Beginners (PDP) in 2019 following Decree No. T / 140 / E3 / RA.00 / 2019.

\section{REFERENCES}

[1] A. R. Taufik, A. Djamhuri, and E. Saraswati, "Performance Measurement Using Balanced Scorecard (BSC) (Study at Hospitals in Pasuruan)," J. Account. Bus. Educ., vol. 3, no. 1, p. 1, Sep. 2018, doi: 10.26675/jabe.v3i1.11553.

[2] Y. D. Nur and S. Haksama, "Pengukuran Kinerja Rawat Inap Berdasarkan Perspektif Balanced Scorecard," J. Adm.
Kesehat. Indones., vol. 4, no. 1, p. 67, Dec. 2016, doi: 10.20473/jaki.v4i1.2016.67-76.

[3] S. E. Kaplan, M. J. Petersen, and J. A. Samuels, "An Examination of the Effect of Positive and Negative Performance on the Relative Weighting of Strategically and Non-Strategically Linked Balanced Scorecard Measures," Behav. Res. Account., vol. 24, no. 2, pp. 133-151, Nov. 2012, doi: 10.2308/bria-50114.

[4] W. Arisandy, "Strategi Dinas Kesehatan dalam Meningkatkan Kualitas Pelayanan Kesehatan melalui Metode CRC (Citizen Report Card) di Kota Surabaya," $J$. Kebijak. dan Manaj. Publik, vol. 3, no. 2, pp. 12-23, 2015, available at: http://journal.unair.ac.id/downloadfullpapers-kmp6039f029b9full.pdf.

[5] P. Petera, J. Wagner, and M. Menšík, "Strategic Performance Measurement Systems Implemented in the Biggest Czech Companies with Focus on Balanced Scorecard - An Empirical Study," $J$. Compet., vol. 4, no. 4, pp. 67-85, Dec. 2012, doi : 10.7441/joc.2012.04.05.

[6] Z. Lin, Z. Yu, and L. Zhang, "Performance outcomes of balanced scorecard application in hospital administration in China," China Econ. Rev., vol. 30, pp. 115, Sep. 2014, doi: 10.1016/j.chieco.2014.05.003.

[7] C. W. Chow, D. Ganulin, K. Haddad, and J. Williamson, "The Balanced Scorecard: A Potent Tool for Energizing and Focusing Healthcare Organization Management," $J$. Healthc. Manag., vol. 43, no. 3, pp. 263280, May 1998, doi: 10.1097/00115514199805000-00010.

[8] A. Abofaied, "Evaluation of Bank's Performance by Using Balanced Score Card: Practical Study in Libyan Environment," Int. J. Bus. Manag., vol. 5, no. 1, pp. 1-14, 2017, doi: 10.20472/BM.2017.5.1.001.

[9] Suharno, "Integration of SWOT-Balanced Scorecard to Formulate Strategic Planning in The Technology and Vocational Education in Indonesia," J. Tech. Educ. Train., vol. 8, no. 2, pp. 62-71, 2016, available at: https://publisher.uthm.edu.my/ojs/index.p hp/JTET/article/view/1259.

[10] N. Kopecka, "The Balanced Scorecard 
Implementation, Integrated Approach and the Quality of Its Measurement," Procedia Econ. Financ., vol. 25, pp. 59-69, 2015, doi: 10.1016/S2212-5671(15)00713-3.

[11] M. A. Salem, N. Hasnan, and N. H. Osman, "Balanced scorecard: Weaknesses, strengths, and its ability as performance management system versus other performance management systems," J. Environ. Earth Sci., vol. 2, no. 9, pp. 19, 2012, available at: https://iiste.org/Journals/index.php/JEES/ article/view/3043.

[12] Z. T. Anggraini and E. Nuraina, "Penerapan Balanced Scorecard Sebagai Alat Ukur Kinerja pada Rumah Sakit Umum Dr. Harjono Ponorogo," Assets J. Akunt. dan Pendidik., vol. 3, no. 2, p. 153, Oct. 2014, doi: 10.25273/jap.v3i2.1220.

[13] N. Ummi and H. Setiawan, "Penerapan Balanced Scorecard Sebagai Dasar SWOT Analisis dalam Perancangan Strategi Pengembangan Divisi PPIC di PT. X," in Seminar Nasional Teknik Industri Universitas Gajah Mada, 2015, pp. E92E102, available at: http://digilib.mercubuana.ac.id/manager/t! @ file_artikel_abstrak/Isi_Artikel_396277 236994.pdf.

[14] A. Afonina, "Strategic Management Tools and Techniques and Organizational Performance: Findings from the Czech Republic," J. Compet., vol. 7, no. 3, pp. 19-36, Sep. 2015, doi: 10.7441/joc.2015.03.02.

[15] R. E. Sari and A. Saleh, "Penilaian kinerja dosen dengan menggunakan metode AHP (Studi kasus: di STMIK Potensi Utama Medan)," in Seminar Nasional Informatika (SNif), 2014, vol. 1, no. 1, pp. 108-114, available at: http://e-journal.potensiutama.ac.id/ojs/index.php/SNIf/article/vie $\mathrm{w} / 230$.

[16] T. Yaghoobi and F. Haddadi, "Organizational performance measurement by a framework integrating BSC and AHP," Int. J. Product. Perform. Manag., vol. 65, no. 7, pp. 959-976, Sep. 2016, doi: 10.1108/IJPPM-01-2015-0001.

[17] R. E. Sari, A. Meizar, D. H. Tanjung, and A. Y. Nugroho, "Decision making with AHP for selection of employee," in 2017 5th International Conference on Cyber and
IT Service Management (CITSM), 2017, pp. $1-5, \quad$ doi: 10.1109/CITSM.2017.8089285.

[18] N. Khalil, S. N. Kamaruzzaman, and M. R. Baharum, "Ranking the indicators of building performance and the users' risk via Analytical Hierarchy Process (AHP): Case of Malaysia," Ecol. Indic., vol. 71, pp. 567-576, Dec. 2016, doi: 10.1016/j.ecolind.2016.07.032.

[19] S. Rochmani, A. Fudholi, and L. Hakim, "Analisis Faktor Internal-Eksternal Terhadap Pengelolaan Obat Di Instalasi Farmasi RSUD DR. Moewardi Surakarta," JPSCR J. Pharm. Sci. Clin. Res., vol. 1, no. 1, pp. 10-20, 2016, available at: https://jurnal.uns.ac.id/jpscr/article/view/6 84.

[20] D. Novanda and D. Novanda, "Implementasi integrasi swot balanced scorecard dalam perancangan sistem pengukuran kinerja PT grafika jaya sumbar," Thesis, Universitas Andalas, 2014, available at: http://repo.unand.ac.id/3119/.

[21] I. Budiman, U. P. P. Tarigan, A. Mardhatillah, A. C. Sembiring, and W. Teddy, "Developing business strategies using SWOT analysis in a color crackers industry," J. Phys. Conf. Ser., vol. 1007, no. 1, p. 012023, Apr. 2018, doi: 10.1088/1742-6596/1007/1/012023.

[22] W. Wiyanto, E. Soekarjono, and B. Hasmanto, "Strategi Bersaing Dalam Rangka Menghadapi MEA (Studi Kasus Rs. Bhakti Asih Karang Tengah Tangerang)," J. Pemasar. Kompetitif, vol. 1, no. 3, pp. 93-111, Mar. 2018, doi: 10.32493/jpkpk.v1i3.1146.

[23] E. Hanafi and Z. Fatma, "The Effect of The Integration Between Levers of Control and SWOT Analysis on Organizational Performance: Balanced Scorecard Approach," Int. J. Acad. Res., vol. 7, no. 1, pp. 215-221, 2015, available at: http://scholar.cu.edu.eg/sites/default/files/ fzaki/files/201533b-37.pdf.

[24] H. Rahimi, J. Bahmaei, P. Shojaei, Z. Kavosi, and M. Khavasi, "Developing a Strategy Map to Improve Public Hospitals Performance with Balanced Scorecard and DEMATEL Approach," Shiraz E-Medical J., vol. 19, no. 7, p. e64056, Jun. 2018, doi: 
10.5812/semj.64056.

[25] D. A. A. Malgwi and H. Dahiru, "Balanced Scorecard financial measurement of organizational performance: A review," IOSR J. Econ. Financ., vol. 4, no. 6, pp. 01-10, 2014, doi: 10.9790/5933-0460110.

[26] H. Rahimi, Z. Kavosi, P. Shojaei, and E. Kharazmi, "Key performance indicators in hospital based on balanced scorecard model," J. Heal. Manag. Informatics, vol. 4, no. 1, pp. 17-24, 2017, available at: http://jhmi.sums.ac.ir/article_42683.html.

[27] I. Gabcanova, "Human Resources Key Performance Indicators," J. Compet., vol. 4, no. 1, pp. 117-128, Mar. 2012, doi: 10.7441/joc.2012.01.09.

[28] M. Khalifa and P. Khalid, "Developing Strategic Health Care Key Performance Indicators: A Case Study on a Tertiary Care Hospital," Procedia Comput. Sci., vol. 63, pp. 459-466, 2015, doi: 10.1016/j.procs.2015.08.368.

[29] V. Capkun, M. Messner, and C. Rissbacher, "Service specialization and operational performance in hospitals," Int. J. Oper. Prod. Manag., vol. 32, no. 4, pp. 468-495, Mar. 2012, doi: 10.1108/01443571211223103.

[30] C. McDermott and G. N. Stock, "Hospital operations and length of stay performance," Int. J. Oper. Prod. Manag., vol. 27, no. 9, pp. 1020-1042, Aug. 2007, doi: 10.1108/01443570710775847.

[31] A. Anuar, R. Saad, and R. Z. Yusoff, "Operational Performance and Lean Healthcare in the Healthcare Sector: Review on the Dimensions and Relationships," Int. J. Acad. Res. Bus. Soc. Sci., vol. 8, no. 4, pp. 276-292, 2018, available at: https://ideas.repec.org/a/hur/ijarbs/v8y201 8i4p276-292.html.

[32] D. Podgórski, "Measuring operational performance of OSH management system - A demonstration of AHP-based selection of leading key performance indicators," Saf. Sci., vol. 73, pp. 146-166, Mar. 2015, doi: 10.1016/j.ssci.2014.11.018.

[33] I. Kesuma, "Analisis Penilaian Kinerja Rumah Sakit Dengan Penerapan Balanced Scorecard (Studi Kasus Rumah 'ABC')," J. Sist. Inf., vol. 3, no. 1, pp. 1-7, 2014, available http://repository.unsri.ac.id/9358/.

[34] R. Freddy, SWOT Balanced Scorecard (Teknik Menyusun Strategi Korporat yang Efektif plus Cara Mengeola Kinerja dan Risiko). Jakarta: Gramedia Pustaka Utama, 2011. available at: Google Scholar. 